\title{
Salvar o passado? Proust e Benjamin
}

\section{Sybil Safdie Douek}

Resumo: Este artigo pretende, inspirando-se em alguns escritos de Jeanne Marie Gagnebin, estabelecer correspondências entre a memória involuntária proustiana e o conceito benjaminiano de rememoração (Eingedenken). $\mathrm{O}$ passado não volta tal como foi vivido, mas sim, renovado, recriado, um novo passado. O desejo de 'salvar o passado' parece ser compartilhado por Benjamin e Proust, embora para cada um dos autores, o significado de tal salvação ressoe de modo diverso.

Palavras chave: memória involuntária. rememoração; salvar o passado.

Walter Benjamin, ao qual fui apresentado por Jeanne Marie Gagnebin nos anos 80, foi, como se sabe, tradutor e admirador de Proust, a ponto de considerá-lo "O narrador por excelência" num mundo onde narração e experiência estão extintas. Em Proust, Benjamin encontrou alguém que, como ele, quis 'salvar' o passado, através da memória involuntária. Tal conceito, aparentemente trivial, após a noção freudiana de inconsciente, tem, entretanto, notáveis repercussões com respeito à relação que o presente entretém com o passado, destruindo, por assim dizer, a ideia corrente de um passado puro que o presente neutro traz à tona, aproximando-se assim da concepção benjaminiana de memória. É o que se pode perceber a partir dos escritos de Benjamin sobre Proust, particularmente A "Imagem de Proust" e alguns trechos de "Sobre algunsmMotivos em Baudelaire", textos que permitem estabelecer correspondências entre o Eingedenken (rememoração) e a memória involuntária.

É em À la recherche du temps perdu, no primeiro volume desta obra monumental, intitulado "Du Côté de chez Swann", que se introduz a questão da memória involuntária. Trata-se do famoso episódio da madeleine, um tipo de bolo bem comum na França. Ao comer um pedaço de madeleine, mergulhado numa xícara de chá, Proust, que antes estava tomado por um desânimo quase invernal, sente-se invadir por intensa felicidade, mais até do que felicidade: "Já não me sentia medíocre, contingente, mortal." ${ }^{1}$ Vê-se logo o que está em jogo: não a felicidade, mas a morte! Sem saber de onde lhe vem tal sensação, Proust procura compreender o que lhe ocorreu. "E de súbito a lembrança me apareceu." 2 De repente, Proust lembra-se de quando comeu o mesmo bolinho misturado ao chá que lhe oferecia sua tia em Combray. A partir daí, é a cidade de Combray inteira e a infância de Proust que voltam a visitá-lo. O gosto do bolinho molhado pelo chá traz a Proust sua infância, sua memória. Esse gesto, aparentemente insignificante, devolve a Proust o que com esforço consciente vinha tentando realizar sem sucesso.

Antes do episódio da madeleine, Proust tentava lembrar-se de sua infância em Combray, mas conclui que este esforço é inútil e vão: 
Mas como o que na época eu lembrasse me seria oferecido exclusivamente pela memória voluntária, a memória da inteligência, e como as informações que ela nos dá sobre o passado nada conservam dele, nunca teria sentido interesse em imaginar o resto de Combray. Tudo aquilo de fato estava morto para mim [...]. É trabalho baldado procurar evocá-lo [o passado], todos os esforços de nossa inteligência serão inúteis. Está escondido, fora de seu domínio e de seu alcance, em algum objeto material (na sensação que este objeto material nos daria), que estamos longe de suspeitar. Tal objeto, depende apenas do acaso que o reencontremos antes de morrer, ou que não o encontremos jamais. ${ }^{3}$

A memória voluntária, da inteligência, que procede informativamente, nada nos diz sobre o passado. É inútil tentar evocá-lo por um esforço da inteligência. Só a partir de um encontro fortuito com um objeto do passado e com a sensação que ele nos despertou e nos desperta hoje é que a memória involuntária é capaz de ressuscitar o passado, de fazê-lo reviver hoje. Esse passado que estava morto, ressuscita, despertado por sutis sensações, situações comuns e triviais. Na memória involuntária, são os pequenos detalhes que fazem reviver o passado em nós:

Mas, quando nada subsiste de um passado antigo, depois da morte dos seres, depois da destruição das coisas, sozinhos, mais frágeis, porém mais vivazes, mais imateriais, mais persistentes, mais fiéis, o aroma e o sabor permanecem ainda por muito tempo, como almas, a lembrar-se, a aguardar, a esperar, sobre a ruína de tudo o mais, carregando sem ceder, sobre suas gotículas quase impalpáveis, o imenso edifício das recordações. ${ }^{4}$

Odores, sabores, sons persistem e subsistem como almas encerradas em algum objeto, e quando o acaso nos coloca em contato com tal objeto, elas dele se desprendem, e nos oferecem o passado que ali estava preso. Essa memória, por assim dizer, corporal, memória inscrita nas sensações (o gosto de um bolinho mergulhado no chá, um passo dado em falso, o barulho de uma colher) traz repentinamente de volta um passado que parecia morto. O passado vem, libertado, ressuscita, com violência, com força, bruscamente, ele vem quase sem ser chamado, sem convite, irrompe em nossa vida, no "tempo de agora", no solo de hoje, no presente, interrompendo o tranquilo curso do tempo, salta para o presente, num instante que o salva. Compreende-se que esse episódio aparentemente comum e insignificante tenha despertado o interesse de Benjamin. Esse mágico instante destaca-se no tempo, interrompendo o fluxo contínuo dos acontecimentos: o tempo pára, imobiliza-se, e o passado invade o presente, renasce no presente, revive, pulando o tempo cronológico e devorador dos relógios.

Poder-se-ia então afirmar que o tempo da Busca situa-se fora da cronologia? Como habitualmente nas diferentes leituras da obra de Proust, a questão, aliás, essencial para os propósitos do presente trabalho, da cronologia, também suscita controvérsias. O próprio Proust não ajuda a esclarecer a questão: como assinala Shattuck, em As Ideias de Proust, pode-se ler num trecho, no qual Gilberte e Marcel rompem: "(já que nossa vida é tão pouco cronológica e insere tantos anacronismos na sequência dos dias)", e em outro, no qual Saint Loup e Charlus ficam velhos: "Tudo é uma questão de cronologia"5 
Evidentemente, como astuciosamente nota o próprio Shattuck, "pode-se demonstrar quase tudo com citações da Busca", 6 escolhendo "astutamente em 3000 páginas de uma longa prosa". ${ }^{7}$ Talvez não sem certa astúcia, vem-me à cabeça, o fato de que Marcel só tenha se dado conta da magnitude de seu sofrimento por ocasião da morte de sua avó, muitos meses depois, não havendo coincidência entre o calendário dos fatos e o dos sentimentos. Os fatos podem encadear-se cronologicamente, e o tempo devorador dos relógios é inexorável, como bem o demonstra uma das últimas cenas: a recepção na casa dos Guermantes, na qual o tempo, sob a forma do envelhecimento, impede até mesmo o reconhecimento dos personagens. Mas, ao lado da destruidora cronologia, insinua-se outro tempo, tempo da memória involuntária, que se insurge contra a monótona badalada dos relógios, e que torna possível viver no "agora", um passado remoto e longínquo, saltando por cima dos acontecimentos, tornando o passado vivo hoje. A memória involuntária proustiana opera por saltos, na expressão de Shattuck, assim como o salto do tigre de Benjamin é surgimento, ou irrupção do passado no presente e, nesse surgimento, criação.

O passado ressuscitado pela memória involuntária proustiana também é, num certo sentido, criação: ${ }^{8}$ Proust não fala de sua vida tal como ela realmente foi, mas sim como ele dela se lembra, diz Benjamin em "A Imagem de Proust" insistindo no fato de que o passado nunca volta enquanto tal: distância entre vida vivida e vida lembrada que Proust não cansa de sublinhar.

O trabalho da memória não consiste em fazer corresponder a lembrança a uma realidade vivida: esta talvez seja a infrutífera e vã tarefa que persegue a memória voluntária, mas para aquele que se entrega à autêntica rememoração, o que importa não é o passado em si, mas a própria recordação, "o tecido de sua rememoração, o trabalho de Penélope da reminiscência." E, numa surpreendente reviravolta, Benjamin transforma a monumental obra de Proust em elogio do esquecimento:

Ou seria preferível falar do trabalho de Penélope do esquecimento? A memória involuntária, de Proust, não está mais próxima do esquecimento que daquilo que em geral chamamos de reminiscência? Não seria este trabalho de rememoração espontânea, em que a recordação é a trama e o esquecimento a urdidura, o oposto do trabalho de Penélope, mais que sua cópia? ${ }^{10}$

Atendendo ao apelo da memória involuntária, memória que a clara luz da consciência não domina, memória que vem sem ser chamada, o eu arrisca-se ao esquecimento. Para lembrar é preciso se arriscar a esquecer, como ressalta Blanchot:

Quem, mais do que Proust, deseja lembrar-se de si próprio? Por isso, não há escritor mais estranho ao registro da sua vida dia a dia. Aquele que quer lembrar-se deve confiar-se ao esquecimento, a esse risco que é o esquecimento absoluto e a esse belo acaso que se torna então a lembrança. ${ }^{11}$

Lembrar/esquecer, claro, duas faces da mesma moeda: não há lembrança possível sem esquecimento. Mas não é só disto que fala Proust: ao recusar as verdades retas das lembranças ordenadas, submetidas ao controle da consciência, ele abre espaço 
para o universo do desorganizado, do imprevisível, correndo o risco, assinalado por Blanchot "o risco do esquecimento absoluto".

Lembrar não é fugir do esquecimento, mas, ao contrário, a ele entregar-se. A memória voluntária, da inteligência, que pretende catalogar os fatos imutáveis do passado numa história em que os momentos encadeiam-se "como as contas de um rosário", ${ }^{12}$ que age informativamente, fazendo um "inventário dos achados", ${ }^{13}$ na verdade não traz nada sobre o passado. Benjamin, em "Imagens do Pensamento", estabelece uma analogia entre a atividade do lembrar e a escavação arqueológica: a memória é escavação. Ao escavar, encontram-se restos, ruínas, vestígios no solo de hoje, e é a partir deles que se reconstrói o passado, mas nunca como de fato foi. Nesse sentido, Benjamin aproxima-se de Proust e da memória involuntária, que recria um passado no presente a partir de um odor, um sabor, um detalhe inesperado, que carrega consigo uma torrente de lembranças que invadem o presente, torrente na qual a imagem do passado não corresponde ao passado 'em si', como de fato aconteceu, passado ressuscitado no "agora".

Entretanto, se o episódio da madeleine é, sem dúvida, absolutamente central na Recherche e não pode ser reduzida aos momentos de felicidade proporcionados pelo reencontro com o passado. Jeanne Marie Gagnebin, ao confrontar a Busca com outros escritos de Proust, notadamente Jean Santeuil e o prefácio de Contre SainteBeuve, deixa claro que não se deve considerá-la apenas "um belo romance que enumera e descreve vários momentos, vários instantes privilegiados e felizes que chegam ao acaso e pegam de surpresa o herói." 14

Também para Roger Shattuck, o prefácio de Contre Sainte-Beuve revela a "impaciência de Proust”, pois, ali, Proust narra em “[...] três páginas rápidas [...] as três ressurreições clássicas: a torrada mergulhada no chá; as lajes desiguais do calçamento; o retinir da colher num prato." 15 A rapidez que caracteriza essa passagem passa ao largo da verdadeira tarefa que se impôs Proust na Busca. Como diz Jeanne Marie Gagnebin, não se trata somente de reencontrar a sensação em si, mas, sobretudo:

da passagem da sensação enquanto tal [...] para sua nomeação, seu reconhecimento, que desencadeia um gigantesco processo de conhecimento e de produção - ou seja, a escrita desse imenso livro. [...] Para ele, não se trata de escrever um romance de impressões seletas e felizes, mas sim de enfrentar, por meio da atividade intelectual e espiritual que o exercício da escrita configura, a ameaça do esquecimento, do silêncio e da morte. ${ }^{16}$

Por isso mesmo, as três páginas de Contre Sainte-Beuve se transformarão em três mil na Busca do tempo perdido, revelando uma diferença não somente quantitativa, mas uma decisiva mudança de perspectiva: "A verdade não deve surgir depressa demais." ${ }^{17}$ Ela é apenas sutilmente sugerida, no início do primeiro volume da Busca, para ser revelada apenas nas últimas páginas do Tempo Redescoberto, volume derradeiro desta obra monumental. Tal sutileza, aponta Ricoeur, reveste a forma de um simples parêntese. Ao sentir o gosto da madeleine, como já foi mencionado, Proust é invadido por intensa felicidade, cuja causa entretanto, ele desconhece:

Invadira-me um prazer delicioso, isolado, sem a noção de sua causa (...). Já não me sentia medíocre, contingente, mortal. De onde poderia ter vindo essa alegria poderosa? Sentia que estava ligada ao gosto do chá e do 
biscoito, mas ultrapassava-a infinitamente, não deveria ser da mesma espécie. De onde vinha? Que significaria? Onde apreendê-la? ${ }^{18}$

Diz Ricoeur, ao comentar esta passagem:

Ora, a pergunta assim colocada contém a armadilha de uma resposta curta demais, que seria simplesmente a da memória involuntária. [...] Que não seja assim, é mostrado por um único indício para o leitor de ouvidos apurados; trata-se de um parêntese; que diz: '(embora ainda não soubesse e tivesse de deixar para muito mais tarde a descoberta de por que essa lembrança me tornava tão feliz.) '. ${ }^{19}$

Bem mais tarde, isto é, quase três mil páginas depois. Visitemos pois o famoso episódio da iluminação ou revelação: no último volume, Le Temps Retrouvé, o narrador da Recherche conta como, ao pisar no solo irregular do pátio dos Guermantes, é invadido por um intenso sentimento de felicidade como no episódio da madeleine, situado no início do livro. Assim como Combray saiu de sua xícara de chá, Veneza irrompe com nitidez da irregularidade do solo. A questão com a qual se defronta agora Proust, questão já levantada no início da Recherche, é a de compreender a causa ou origem desta felicidade.

Mas por que motivo as imagens de Combray e de Veneza me haviam, num como noutro momento, comunicado uma alegria semelhante à certeza e suficiente, sem outras provas, para me deixar indiferente à morte $?^{20}$

Pois, diz Proust, o passado transportado para o presente, esta coincidência entre passado e presente, permitiu-lhe viver um momento "fora do tempo", tocando assim a essência das coisas, e neutralizando a morte.

$\mathrm{Na}$ verdade, o ser que então saboreava em mim esta impressão, saboreava-a naquilo que ela possuía em comum entre um dia antigo e o atual, no que possuía de extratemporal, era um ser que só aparecia quando, por uma dessas identidades entre o presente e o passado, podia achar-se no único ambiente em que conseguiria viver, desfrutar da essência das coisas, isto é, fora do tempo. Isto explicava por que minhas inquietações acerca da minha morte teriam cessado no momento em que eu, inconscientemente, reconhecera o gosto do bolinho, pois nesse instante ser que eu fora era um ser extratemporal, por conseguinte despreocupado das vicissitudes do futuro. ${ }^{21}$

É interessante notar aqui que Proust, ao falar de uma experiência tão decisiva, não usa a palavra "eu", mas refere-se ao "ser que estava em mim". Como se essa experiência, de alguma maneira, fosse revestida de certa impessoalidade. O ser extratemporal não pode dizer "eu", é um sujeito, por assim dizer, impessoal, indeterminado, neutro.

A coincidência entre passado e presente, ou melhor, a brusca irrupção do passado no presente faz com que este ser ordinário e ao mesmo tempo extraordinário experimente um momento mágico de extratemporalidade, momento que "[...] permitira a meu ser obter, isolar e imobilizar (na duração de um relâmpago) o que 
jamais apreendera: uma fração de tempo em estado puro", ${ }^{22}$ momento também em que o homem está liberto do jugo do tempo e da morte: "Um minuto liberto da ordem do tempo recriou em nós, para senti-lo, o homem liberto da ordem do tempo." ${ }^{23}$ Assim, o homem de certa forma alcança a eternidade, mesmo que por um fugaz instante, um veloz vislumbre, num relampejo: "fragmentos de existência subtraídos ao tempo; mas essa contemplação, embora de eternidade, era fugaz." 24

Uma rápida leitura permitiria identificar este momento de extratemporalidade com a eternidade. No entanto, a leitura mais atenta e perspicaz de Blanchot aponta a contradição existente entre este tempo abolido pelo próprio tempo ("Eis, pois, o tempo apagado pelo próprio tempo." 25 ) e a experiência de ter conseguido apreender "um pouco de tempo em estado puro":

Porque esta reviravolta? Por que razão o que está fora do tempo põe à sua disposição o tempo puro? [...] Viver a abolição do tempo, viver esse movimento, rápido como o 'relâmpago', pelo qual dois instantes, infinitamente separados, vêm 'pouco a pouco embora imediatamente' ao encontro um do outro, unindo-se como duas presenças que, pela metamorfose do desejo, se identificassem, é percorrer toda a realidade do tempo, e ao percorrê-la experimentar o tempo como espaço e lugar vazio, quer dizer, livre dos acontecimentos que habitualmente o preenchem. ${ }^{26}$

O "fora do tempo" não pode ser assimilado unicamente à eternidade, mas também a um tempo puro, isto é, abolido, apagado, liberto de acontecimentos, um tempo pensado como espaço vazio. De que tempo se trata? Trata-se propriamente, diz Blanchot, do "próprio tempo da narrativa, o tempo que não está fora do tempo, mas que se experimenta como exterior, sob a forma de um espaço, esse espaço imaginário onde a arte acha e dispõe os seus recursos." ${ }^{27}$ Tempo vazio que se transforma em espaço imaginário, espaço da narrativa, da literatura, espaço secreto da possibilidade de escrever. O tempo propriamente da escrita, tempo que permite a Proust ter certeza que ele é agora um escritor, que tocou a essência mesma da literatura: Proust colocou-se "nesse tempo da escrita em que parece que é o próprio tempo que, em vez de se perder em acontecimentos, vai começar a escrever [...]". ${ }^{28}$

Eis aqui, numa vertiginosa reviravolta, o tempo vazio no qual se inscrevem acontecimentos, tempo do historicismo tão criticado por Benjamin, subitamente desprovido dos próprios acontecimentos que o preenchem. Ei-lo em sua solitária presença, em sua positividade plena, desprezando os acontecimentos cronológicos, saltando fora deles, para criar o espaço imaginário da escrita.

Se Blanchot foge assim de uma interpretação apressada que identificaria o extratemporal com a eternidade, para Benjamin também o tempo proustiano não pode ser entendido como sinônimo de eternidade: "Com razão, Fernandez distinguiu, em Proust, um thème de l'éternité de um thème du temps. Mas essa eternidade não é de modo algum platônica ou utópica: ela pertence ao registro da embriaguez." ${ }^{29} \mathrm{Se}$ Proust não menciona explicitamente a embriaguez, fala, no entanto, de uma quase "perte de connaissance", um quase desmaio, uma vertigem, em que a certeza da consciência é colocada em xeque: o eu, por assim dizer, perde-se, esvazia-se, quase se esvai.

Nessas ressurreições, o local distante engendrado em torno da sensação comum sempre se agarrava, por um momento, como um lutador, ao local 
de hoje. E o local de hoje sempre fora vencedor; e sempre o vencido é que me parecera mais belo. [...] E, se o lugar atual não fosse logo vitorioso, creio que desmaiaria. ${ }^{30}$

Seria interessante a esse respeito evocar a tese de Georges Poulet, para o qual o que predomina na obra de Proust não é o tempo, mas sim o espaço perdido: “O tempo cede lugar ao espaço". ${ }^{31}$ Diz Poulet, se opondo aos que querem ver na Recherche um exemplo vivo da duração bergsoniana. Sem entrar em pormenores ou discutir se o que predomina na obra de Proust é o espaço ou a duração, não se pode deixar de notar que a referência espacial ocupa um importante lugar na Recherche, como por exemplo no trecho acima, no qual Proust descreve o movimento pelo qual o passado invade o presente: neste movimento, há como que um duelo entre o lugar passado e o presente. Para Poulet, não somente o tempo, mas também os lugares vacilam, se movem, deslocam-se, provocando uma desorientação espacial: "A ressurreição do passado, diz Proust, em resumo, força nosso espírito a 'trébucher' (tropeçar) entre lugares remotos e lugares presentes" 32 a tal ponto que não se sabe mais onde se está: vertigem, atordoamento dos quais não se cansa de falar Proust: " "no atordoamento de uma incerteza semelhante à que por vezes sentimos diante de uma visão inefável, ao adormecermos'."33

O espírito "tropeça", a clara luz da consciência se ofusca, os limites do 'eu' tornam-se mais fluídos: talvez seja isto que Benjamin chame "embriaguez", na qual se situa o extratemporal.

Mesmo que esse ser fora do tempo não seja identificado com a eternidade, mas revele "uma concepção muito mais paradoxal, que vê aí a essência mesma do tempo, 'um pouco de tempo em estado puro' [...]" é importante salientar que "a teoria proustiana da estética, em compensação, se decide pela ancoragem no eterno" 34

A função da arte seria a de capturar esse momento privilegiado em que presente e passado se fundem e se misturam, revelando a eternidade. $O$ único meio pelo qual se pode fixar esta "contemplação da essência das coisas" 35 é a obra de arte. A essência das coisas se expressa através obra de arte, diante da qual não somos livres, pois ela preexiste a nós: o verdadeiro artista é aquele que a descobre, que se submete à realidade interior e é capaz de decifrar seus signos; o escritor é um tradutor:

Esse livro essencial, o único livro genuíno, um grande escritor não precisa inventá-lo, no sentido comum, pois ele já existe em cada um de nós, e sim traduzi-lo. O dever e a tarefa de um escritor são os de um tradutor. ${ }^{36}$

Assim como, para Platão, conhecer é apenas recordar-se da verdade que outrora se contemplou, escrever é apenas traduzir, ou decifrar os signos de uma realidade preexistente a nós. A arte é mensageira de eternidade, através dela o homem pode contemplar a essência das coisas, essência já inscrita no próprio homem: a tarefa do escritor é deixar que essa essência fale através dele, o que ele deve fazer é traduzi-la. Tal concepção estética, na qual "subsistem traços de idealismo", ${ }^{37}$ será objeto de crítica de Benjamin, que diminuirá a importância que lhe atribui o próprio Proust, privilegiando outra dimensão da obra proustiana: a análise do esnobismo: "A análise proustiana do esnobismo, muito mais importante que sua apoteose da arte, é o ponto alto de sua crítica social." ${ }^{38}$ Esta objeção que Benjamin dirige a Proust não é somente referente à estética, mas revela as diferenças mais profundas que separam os dois autores. 
As afinidades entre Proust e Benjamin não podem, portanto, escamotear as diferenças que separam esses dois autores obcecados pela memória: enquanto, para Proust, a ressurreição da memória oferece um instante de extratemporalidade, que pode ser imortalizado através da arte, para Benjamin, não se pode fugir do tempo: a ressurreição desemboca numa filosofia da história, os elementos inacabados do passado, estes "torsos na galeria do colecionador" 39 devem possibilitar uma nova escrita da história passada, um "escovar a história a contrapelo". ${ }^{40}$ Não se pode fugir do tempo: é preciso, ao contrário, se reapropriar dos elementos inacabados do passado e fazê-los reviver no presente, retomar a história, reescrevê-la: e isto não é função do artista, mas do historiador materialista e da ação política.

Para Benjamin a tarefa do historiador materialista não é a de correr atrás de um passado que já foi, mas de reconstruí-lo a partir de suas ruínas, de seus cacos. Tratase não somente de contar as histórias que não foram contadas, a história dos vencidos, mas também de reconstruir o passado para libertá-lo, para fazer aflorar nele aquilo que ele próprio não realizou, reacender a esperança e o futuro que não foram possíveis. É preciso, nesse presente, poder construir o futuro do passado. A salvação do passado está nessa libertação, nesse futuro do passado que pode se tornar presente. Lembremo-nos do anjo que quer "demorar-se, despertar os mortos e juntar os destroços." 41

Compreende-se então, em primeiro lugar, que, para Benjamin, tal tarefa não possa ser deixada ao sabor do acaso: "Não é de modo algum evidente este depender do acaso", ${ }^{42}$ mas é decisão ética daquele que deliberadamente toma para si a responsabilidade de liberar o passado, ascendendo-lhe a esperança que não foi cumprida, oferecendo sua frágil força messiânica às vozes do passado que ecoam no presente.

E, em segundo, que o resgate do passado não possa ser assunto individual: só pode ser pensado em termos coletivos. É o que sugere a feliz metáfora da arqueologia, que aparece em "Escavando e Recordando" 43 : ela indica que o passado é legado comum a todos os homens; e, assim como os achados arqueológicos anunciam acontecimentos que se referem à humanidade, e só adquirem sentido na ligação com ela, a memória deve mergulhar suas raízes no coletivo: é também daí que retira seu sentido mais fundamental.

É bem verdade que a matéria prima com a qual trabalha Proust é o indivíduo e seu Erlebnis. Mas Proust teria conseguido "reintroduzir o infinito nas limitações da existência individual burguesa", ${ }^{44}$ infinito que se revela na busca empreendida pela memória, nessa busca infinita de um tempo perdido, onde o essencial não se encontra no conteúdo da lembrança trazida à tona, mas no próprio movimento da memória, no "actus purus da própria recordação". ${ }^{45}$ Proust ultrapassa os limites do individual, através da dinâmica e do jogo infinitos do lembrar, abrindo para vivência (Erlebnis) a amplitude da experiência (Erfahrung). "Pois um acontecimento vivido é finito [...] ao passo que o acontecimento lembrado é sem limites." 46 O Erlebnis proustiano amplia-se e desdobra-se em Erfahrung. Questão problemática, de difícil resolução, até mesmo enigmática, se pensarmos o Erfahrung e Erlebnis enquanto duas instâncias excludentes e não interpenetráveis. Mas, se o próprio Benjamin admite que Proust consegue construir uma experiência a partir da vivência, pode-se portanto, conceber uma 'porosidade', uma circulação entre esses dois conceitos: eles não são estanques, nem excludentes. Talvez seja Pierre Nora quem de modo mais conciso e contundente formulou esta questão: "Não devemos efetivamente a Freud e a Proust os dois lugares de memória íntimos e ao mesmo tempo universais que são a 
cena primitiva e a pequena madalena?" 47 Memória íntima e, ao mesmo tempo, universal: Freud e Proust referem-se ao indivíduo, mas ultrapassam-no numa experiência coletiva, que diz respeito a todos os homens e se repete em cada homem. O Erlebnis transmuta-se em Erfahrung.

Quando Proust descreve, numa passagem célebre, essa hora supremamente significativa, ele o faz de tal maneira que cada um de nós reencontra essa hora em sua própria existência. Por pouco, poderíamos chamá-la uma hora que se repete todos os dias. ${ }^{48}$

Possibilidade que era oferecida pela comemoração das festas e pelos cultos e que Proust tentou recuperar com sua Recherche: a memória proustiana diz mais respeito ao tempo das festas inscritas no calendário do que ao tempo dos relógios.

O próprio Benjamin distingue tempo do calendário e tempo dos relógios na Tese 15 de "Sobre o conceito da história":

a Grande Revolução introduziu um novo calendário. O dia com o qual começa o novo calendário funciona como um acelerador de tempo histórico. E, no fundo, é o mesmo dia que retorna sempre na figura dos dias de festa, que são dias da rememoração. Os calendários, portanto, não contam o tempo como relógios. ${ }^{49}$

O tempo dos relógios é aquele que corre sempre igual, em que as horas se sucedem em sua monotonia, tempo homogêneo e vazio do historicismo, que Benjamin para, como Josué, para instaurar outro tempo, o dos calendários, das festas onde o tempo se imobiliza para convocar um evento passado, um mesmo dia que volta a cada vez renovado, reatualizado no presente, da mesma maneira que Robespierre citava, convocava e ressuscitava a Roma Antiga. Este tempo outro, do calendário e das festas, é o tempo da experiência (Erfahrung) e da tradição: "O homem, para quem a experiência se perdeu, se sente banido do calendário." 50

Tempo dos relógios, tempo dos calendários, temporalidades diferentes que remetem a diferentes dinâmicas da memória: Erinnerung e Eingedeken. O dos calendários é marcado pelo Eingedenken.O tempo dos calendários institui assim uma nova maneira de se relacionar com o passado: este não seria mais objeto de uma reconstituição total, possível graças à Erinnerung que acumula as lembranças e as sobrepõe numa cadeia totalizante e infinita, que se estrutura num fluxo contínuo em que os acontecimentos passados se desenrolam sem cessar, acumulativamente, como no historicismo, ou dialeticamente, como na filosofia da história hegeliana. Benjamin critica esse conceito hegeliano de Erinnerung e de continuidade. O contínuo e infinito desenrolar histórico passa ao largo do momento presente, do "agora" no qual se escreve a história, no qual o tempo imobiliza-se para extrair um fragmento do passado que o Eingedenken recolhe no presente.

A filosofia benjaminiana da história vem, portanto, acompanhada de uma concepção da memória, que não pode mais ser entendida somente em termos da Erinnerung, isto é, lembrar interiorizado e totalizador, sem interrupções, no qual os acontecimentos sucedem-se como "as contas de um rosário" e são recapitulados e catalogados pela memória voluntária, da inteligência. A memória enquanto Eingedenken interrompe o fluxo contínuo do tempo, marcando nele o instante abrupto no qual o passado salta no presente, como um tigre: é essa memória que 
Benjamin identifica tanto em Proust quanto nos cultos e rituais, memória que é ao mesmo tempo rememoração e comemoração.

O Eingedeken, dinâmica da memória que remete ao tempo dos calendários, inscreve-se então no "tempo do agora", na Jetztzeit, que interrompe o continuum da história e "institui a corrente da tradição, que transmite o acontecido de geração a geração". ${ }^{51}$ Compreende-se então que, para Benjamin, a tradição só possa ser descontínua. "O continuum da história é o dos opressores. Enquanto a representação do continuum iguala tudo ao nível do chão, a representação do descontínuo é o fundamento da autêntica tradição." 52

O continuum da história repousa sobre o silêncio dos oprimidos, sobre o sufocar das revoltas dos vencidos, sobre as falhas e lacunas de uma história aparentemente lisa e sem fraturas, história contínua dos vencedores. A tradição dos oprimidos é necessariamente descontínua, como diz Mosès:

Quando a história se encarrega da memória dos vencidos, ela empresta à tradição suas características mais específicas: sua não-linearidade, suas rupturas e intermitências, enfim, a presença nela de uma negatividade radical. Por oposição à racionalidade histórica, fundada sobre a ficção de um fluxo temporal homogêneo ligando um ao outro os instantes que se sucedem, a tradição - transmissão de uma geração à outra de uma memória coletiva - implica por sua própria condição o corte do tempo, a fratura entre as épocas, o vazio cavado entre os pais e os filhos. Se, para Benjamin, a tradição veicula a autêntica consciência histórica, é porque é fundada sobre a realidade da morte. [...] A tradição deve sua verdadeira criatividade ao fato de que ela se choca sem cessar à morte - isto é, à sua própria interrupção - mas que, por cima deste abismo, ela não cessa de se afirmar de novo. ${ }^{53}$

Quando a história deixa de ser uma sucessão de acontecimentos, ou de épocas, para transformar-se em tempo de gerações, introduz em seu seio a ideia de morte e de descontinuidade. Não se pode deixar de enfatizar a profunda originalidade dessa concepção de uma tradição descontínua e a cada vez renovada: a tradição é frequentemente associada a uma continuidade em que não há rupturas, em que o pai transmite ao filho uma palavra que ouviu do seu próprio pai, e que seu filho só faria repetir, anulando o hiato existente entre as gerações, negando tanto a existência da morte e do esquecimento - risco que conheceu Proust com sua memória involuntária, como ressaltaram Blanchot e o próprio Benjamin - quanto do nascimento, isto é, a novidade radical em que implica outra geração. Esta monótona tradição, que transmite uma palavra supostamente sempre igual e repetida, sem fraturas nem silêncios, é aquela que Benjamin menciona em sua Tese 6: "É preciso arrancar a tradição ao conformismo, que está na iminência de subjugá-la." "54 Para arrancar a tradição ao conformismo, é preciso atuar como o materialista histórico que, ao invés de apresentar uma "imagem 'eterna' do passado", como o historicista, faz "uma experiência com o passado que se firma aí única", ${ }^{55}$ experiência única na medida em que esse momento do passado é recriado no solo de hoje e, mesmo que se repita, nunca o faz de modo igual.

A despeito das já apontadas diferenças, a dinâmica da memória involuntária de Proust e o Eingedenken benjaminiano parecem ser cúmplices de um mesmo desejo de 'salvar' o passado, passado que, malgrado as aparências, ainda não passou, pois 
ressuscita no presente a cada vez, reatualizado, renovado, recriado, um novo passado.

Abstract: Inspired by some writings of Jeanne Marie Gagnebin, this article seeks to establish correspondences between the Proustian involuntary memory and Benjamin's concept of remembrance (Eingedenken). The past does not return as it was lived, but it is indeed renovated and rebuilt as a new past. The desire to 'redeem' the past, seems to be shared by Benjamin and Proust, although for both authors, the meaning of such redemption sounds different.

Keywords: involuntary memory; remembrance; redemption.

\section{Referências}

BENJAMIN, Walter. A Imagem de Proust. In: Magia e Técnica, Arte e Política. Trad. Sérgio Paulo Rouanet. São Paulo: Brasiliense, 1985. - (Obras escolhidas; v. 1)

BENJAMIN, Walter. Denkbilder. In: Gesammelte Schriften, v. 4. Frankfurt/M.: Suhrkamp, 1972.

BENJAMIN, Walter. Der Erzähler. Trad. Modesto Carone. In: Gesammelte Schriften, v. 2. Frankfurt/M.: Suhrkamp, 1974.

BENJAMIN, Walter. Erfahrung und Armut. In: Gesammelte Schriften, v. 2, Frankfurt/M.: Suhrkamp, 1974

BENJAMIN, Walter. Experiência e Pobreza. In: Magia e Técnica, Arte e Politica. Trad. Sérgio Paulo Rouanet. São Paulo: Brasiliense, 1985. - (Obras Escolhidas; v. 1)

BENJAMIN, Walter. Imagens do Pensamento. In: Rua de Mão Única. 4. ed., trad. José Carlos Martins Barbosa; Pierre Paul Michel Ardengo. São Paulo: Brasiliense, 1994. - (Obras escolhidas; v. 2).

BENJAMIN, Walter. O Narrador: Observações sobre a obra de Nikolai Leskov. In: Benjamin, Adorno, Horkheimer, Habermas. 2. ed. São Paulo: Abril, 1983. - (Os pensadores)

BENJAMIN, Walter. Sobre alguns temas em Baudelaire. In: Charles Baudelaire, Um Lírico no Auge do Capitalismo. 3. ed., trad. Hemerson Alves Batista; José Carlos Martins Barbosa. São Paulo: Brasiliense, 1995. - (Obras escolhidas, v.3)

BENJAMIN, Walter. Sobre o conceito de história. Trad. Jeanne Marie Gagnebin; Marcos Müller. In: Michael Löwy. Walter Benjamin: aviso de incêndio. Uma leitura das Teses "Sobre o conceito de história". São Paulo: Boitempo, 2005. 
BENJAMIN, Walter. Über den Begiff der Geschichte. In: Gesammelte Schriften, v. 1. Frankfurt/M.: Suhrkamp, 1974, p. 691-704.

BENJAMIN, Walter. Über einige Motive bei Baudelaire. In: Gesammelte Schriften, v. 1. Frankfurt/M.: Suhrkamp, 1974.

BENJAMIN, Walter. Zum Bilde Prousts. In: Gesammelte Schriften, v. 2. Frankfurt/M.: Suhrkamp, 1974.

BLANCHOT, Maurice. Le livre à venir. Paris: Gallimard, 1959, Collection Folio/Essais, 1999.

BLANCHOT, Maurice. O Livro Por Vir. Trad. Maria Regina Louro. Lisboa: Relógio d'Água Editores, 1984.

GAGNEBIN, Jeanne-Marie. "O Rumor das Distâncias Atravessadas". In: Lembrar escrever esquecer. São Paulo: Editora 34, 2006.

GAGNEBIN, Jeanne-Marie. "Prefácio: Walter Benjamin ou a História Aberta", in: Walter Benjamin: Magia e técnica, Arte e Política. São Paulo: Brasiliense, 1985. (Obras escolhidas; v. 1)

GAGNEBIN, Jeanne-Marie. História e Narração em W. Benjamin, São Paulo: Perspectiva, Campinas, Fapesp, 1994.

GAGNEBIN, Jeanne-Marie. Walter Benjamin: Os Cacos da História, São Paulo: Brasiliense, Coleção Encanto Radical, 1982.

LÖWY, Michael. Walter Benjamin: aviso de incêndio. Uma leitura das teses "Sobre o conceito de história". Trad. Wanda Nogueira Caldeira Brandt. São Paulo: Boitempo editorial, 2005.

MOSÈS, Stéphane. L'ange de l'histoire: Rosenzweig, Benjamin, Scholem. Paris: Seuil, 1992.

NORA, Pierre. Entre mémoire et histoire. In: Les lieux de la mémoire, v. 1 - La République, Paris: Gallimard, 1984.

NORA, Pierre. Entre mMemória e história: a problemática dos lugares. Projeto História. Trad. Yara Aun Khoury, v. 10, São Paulo: Educ, dezembro de 1993.

POULET, Georges. L'espace proustien. Paris: Gallimard, 1963.

POULET, Georges. O espaço proustiano. Trad. Ana Luisa B. Martins Costa. Rio de Janeiro: Biblioteca Pierre Menard; Imago, 1992.

PROUST, Marcel. Du Côté de chez Swann. Paris: Flammarion, 1987. - (À la recherche du temps perdu, v. 1) 
PROUST, Marcel. Le Temps Retrouvé, Paris: Gallimard, Livre de Poche, 1954. - (À la recherche du temps perdu, v. 8)

PROUST, Marcel. No Caminho de Swann. 3ed., trad. Fernando Py. Rio de Janeiro: Ediouro, 1992. - (Em Busca do Tempo Perdido, v. 1)

PROUST, Marcel. O Tempo Recuperado. Trad. Fernando Py. Rio de Janeiro: Ediouro, 1995. - (Em Busca do Tempo Perdido, v. 8)

RICOEUR, Paul. A la Recherche du Temps Perdu: Le Temps Traversé. In: La Configuration dans le Récit de Fiction. Paris: Seuil, 1984. - (Temps et Récit ; v. 2)

RICOEUR, Paul. À la recherche du temps perdu: o tempo atravessado. In: $A$ configuração do tempo na narrativa de ficção. Trad. Márcia Valéria Inez de Aguiar, rev. Claudia Berliner. São Paulo: Martins Fontes, 2010. - (Tempo e narrativa; v. 2)

SHATTUCK, Roger. As Idéias de Proust. São Paulo: Cultrix, Co-edição com a Editora da USP, 1985. Tradução brasileira de Eliane Fittipaldi Pereira. Proust, 1974.

\section{Notas}

${ }^{1}$ PROUST, Du Côté de chez Swann, p.142; PROUST, No Caminho de Swann, p. 56.

${ }^{2}$ PROUST, Du Côté de chez Swann, p.144; PROUST, No Caminho de Swann, p. 57.

${ }^{3}$ PROUST, Du Côté de chez Swann, p.141-142; PROUST, No Caminho de Swann, p. 55.

${ }^{4}$ PROUST, Du Côté de chez Swann, p.145; PROUST, No Caminho de Swann, p. 57-58.

${ }^{5}$ SHATTUCK, Proust, p. 112.

${ }^{6}$ SHATTUCK, Proust, p. 120.

${ }^{7}$ SHATTUCK, Proust, p. 114.

8 Cf. PROUST, Du Côté de chez Swan, p.143: "Chercher? Pas seulement: créer." PROUST, No Caminho de Swann, p. 56: "Procurar? Não apenas: criar."

${ }^{9}$ BENJAMIN. A imagem de Proust, p. 37.

${ }^{10}$ BENJAMIN. A imagem de Proust, p. 37.

${ }^{11}$ BLANCHOT, Le Livre à Venir, p. 256-257. BLANCHOT. O Livro Por Vir, p. 196.

${ }^{12}$ BENJAMIN. Sobre o conceito da história, p. 140.

${ }^{13}$ BENJAMIN. Imagens do pensamento, p. 239.

${ }^{14}$ GAGNEBIN, "O rumor das ristâncias rtravessadas", p. 146.

${ }^{15}$ SHATTUCK, As Ideias de Proust, p. 128.

${ }^{16}$ GAGNEBIN, "O Rumor das Distâncias Atravessadas”, p. 154.

${ }^{17}$ SHATTUCK, As Ideias de Proust, p. 129.

${ }^{18}$ PROUST, Du Côté de chez Swann, p.142; PROUST, No Caminho de Swann, p. 56.

${ }^{19}$ RICOEUR, Tempo e Narrativa, v. 2, p. 237.

${ }^{20}$ PROUST. Le Temps Retrouvé, p. 222; PROUST. O Tempo Recuperado, p. 177.

${ }^{21}$ PROUST. Le Temps Retrouvé, p. 226-227; PROUST. O Tempo Recuperado, p. 180181.

22 PROUST. Le Temps Retrouvé, p. 228; PROUST. O Tempo Recuperado, p. 181.

${ }^{23}$ PROUST. Le Temps Retrouvé, p. 228; PROUST. O Tempo Recuperado, p. 182.

${ }^{24}$ PROUST. Le Temps Retrouvé, p. 231; PROUST. O Tempo Recuperado, p. 184.

${ }^{25}$ BLANCHOT. O livro por vir, p. 21. 
${ }^{26}$ BLANCHOT. O livro por vir, p. 21.

${ }^{27}$ BLANCHOT. O livro por vir, p. 21.

${ }^{28}$ BLANCHOT. O livro por vir, p. 22.

${ }^{29}$ BENJAMIN. A imagem de Proust, p. 45.

${ }^{30}$ PROUST. Le Temps Retrouvé, p. 231; PROUST. O Tempo Recuperado, p. 184.

${ }^{31}$ POULET. L'espace proustien; POULET. O espaço proustiano, p. 89.

32 POULET. O espaço proustiano, p. 16/17, ver especialmente p.13 a 23, onde Poulet apresenta vários trechos da obra de Proust que seguiriam esse modelo.

${ }^{33}$ Apud POULET. O espaço proustiano, p. 17.

${ }^{34}$ GAGNEBIN, História e Narração em W. Benjamin, p. 97.

${ }^{35}$ PROUST. Le Temps Retrouvé, p. 232; PROUST. O Tempo Recuperado, p. 185.

${ }^{36}$ PROUST. Le Temps Retrouvé, p. 250; PROUST. O Tempo Recuperado, p. 199.

${ }^{37}$ BENJAMIN. A Imagem de Proust, p. 44.

${ }^{38}$ BENJAMIN. A Imagem de Proust, p. 44.

${ }^{39}$ BENJAMIN. Imagens do pensamento, p. 239.

${ }^{40}$ BENJAMIN. Sobre o conceito da história, p. 70.

${ }^{41}$ BENJAMIN. Sobre o conceito da história, p. 87.

${ }^{42}$ BENJAMIN. Sobre alguns temas em Baudelaire, p. 106.

${ }^{43}$ BENJAMIN. Imagens do pensamento, p. 239.

${ }^{44}$ GAGNEBIN. Prefácio, p. 15.

${ }^{45}$ BENJAMIN. A Imagem de Proust, p. 37.

${ }^{46}$ BENJAMIN. A Imagem de Proust, p. 37.

${ }^{47}$ NORA, Entre Memória e História, p.18.

${ }^{48}$ BENJAMIN. A Imagem de Proust, p. 38.

${ }^{49}$ BENJAMIN. Sobre o conceito da história, p. 123.

${ }^{50}$ BENJAMIN. Sobre alguns temas em Baudelaire, p. 136.

${ }^{51}$ BENJAMIN. O narrador, p. 211.

${ }^{52}$ BENJAMIN. Apud GAGNEBIN, História e Narração em Walter Benjamin, p. 113.

${ }^{53}$ MOSES, L'Ange de l'Histoire, p.158-159.

${ }^{54}$ BENJAMIN. Sobre o conceito da história, p. 65.

${ }^{55}$ BENJAMIN. Sobre o conceito da história, p. 128. 